\title{
DÜBLIN
}

Technological University Dublin

ARROW@TU Dublin

Articles

Crest: Centre for Research in Engineering

Surface Technology

2012-04-15

\section{Effect of N-Doping on the Photocatalytic Activity of Sol-Gel TiO2}

Nicholas Nolan

Technological University Dublin

Damian Synnott

Technological University Dublin, damian.synnott@tudublin.ie

Michael Seery

Technological University Dublin, michael.seery@tudublin.ie

See next page for additional authors

Follow this and additional works at: https://arrow.tudublin.ie/cenresart

\section{Recommended Citation}

Nolan, T. (2012) Effect of N-Doping on the Photocatalytic Activity of Sol-Gel TiO2. Journal of Hazardous Materials, Volumes 211-212, 15 April 2012, pp. 88-94. doi:10.1016/j.jhazmat.2011.08.074

This Article is brought to you for free and open access by the Crest: Centre for Research in Engineering Surface Technology at ARROW@TU Dublin. It has been accepted for inclusion in Articles by an authorized administrator of ARROW@TU Dublin. For more information, please contact arrow.admin@tudublin.ie, aisling.coyne@tudublin.ie, gerard.connolly@tudublin.ie. Funder: Science Foundation Ireland

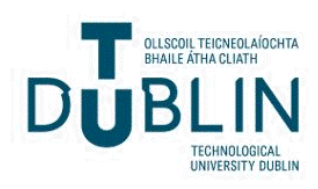


Authors

Nicholas Nolan, Damian Synnott, Michael Seery, Steven Hinder, Axel Van Wassenhaven, and Suresh Pillai

This article is available at ARROW@TU Dublin: https://arrow.tudublin.ie/cenresart/17 


\title{
Effect of N-doping on the photocatalytic activity of sol-gel $\mathrm{TiO}_{2}$
}

\author{
Nicholas T. Nolan a,b, Damian W. Synnotta, ${ }^{\mathrm{a} b}$, Michael K. Seery ${ }^{\mathrm{b}}$, Steven J. Hinder ${ }^{\mathrm{c}}$, \\ Axel Van Wassenhoven ${ }^{\mathrm{d}}$, Suresh C. Pillai ${ }^{\mathrm{a}, *}$ \\ ${ }^{a}$ Centre for Research in Engineering Surface Technology (CREST), Focas Institute, Dublin Institute of Technology, Kevin Street, Dublin 8, Ireland \\ b School of Chemical and Pharmaceutical Sciences, Dublin Institute of Technology, Kevin Street, Dublin 8, Ireland \\ ${ }^{c}$ The Surface Analysis Laboratory, Faculty of Engineering and Physical Sciences, University of Surrey, GU2 7XH, United Kingdom \\ d Institute Paul Lambin, Universite Catholique de Louvain, Clos Chapelle-aux-champs, 43, B-1200 Bruxelles, Belgium
}

\section{A R T I C L E I N F O}

\section{Article history:}

Received 4 May 2011

Received in revised form 26 August 2011

Accepted 29 August 2011

Available online $\mathrm{xxx}$

\section{Keywords:}

Visible light activity

N-doping

Photocatalytic activity

Band gap widening

Degussa p25

Mechanism of doping

Semiconductor photocatalysis

Sol-gel and $\mathrm{TiO}_{2}$

\begin{abstract}
A B S T R A C T
In order to study the visible light photocatalytic activity of nitrogen doped titanium dioxide, the interaction between nitrogen dopant sources and titania precursors during sol-gel synthesis is investigated. $\mathrm{N}-\mathrm{TiO}_{2}$ was synthesised using the sol-gel method using 1,3-diaminopropane as a nitrogen source. Samples were annealed several temperatures and the percentage of rutile present determined by X-ray diffraction to be $0 \%\left(500^{\circ} \mathrm{C}\right), 46 \%\left(600^{\circ} \mathrm{C}\right)$, and $94 \%\left(700^{\circ} \mathrm{C}\right)$. The reducing amounts of anatase at higher temperatures are studied using FTIR, which suggests the absence of any polymeric chains formed by the chelating agents, which would normally extend anatase-to-rutile transformation temperatures. Differential scanning calorimetry shows that crystalliation occurs before $500^{\circ} \mathrm{C}$, providing the crystalline form determined by XRD at $500^{\circ} \mathrm{C}$. Increased temperature also resulted in diminished visible light absorption capability, with only the $500^{\circ} \mathrm{C}$ sample showing significant absorption in the visible region. XPS studies revealed that nitrogen remained within the $\mathrm{TiO}_{2}$ lattice at higher temperatures. Consequent with the reduced visible light absorption capacity, photocatalytic activity also reduced with increased annealing temperature. Degradation kinetics of methylene blue, irradiated with a $60 \mathrm{~W}$ house-bulb, resulted in first order degradation rates constants of $0.40 \times 10^{-2}, 0.19 \times 10^{-2}$, and $0.22 \times 10^{-2} \mathrm{~min}^{-1}$ for 500,600 , and $700^{\circ} \mathrm{C}$ respectively. Degradation of Degussa P25 was minimal under the same conditions, and that of undoped $\mathrm{TiO}_{2}$ was $0.02 \times 10^{-2} \mathrm{~min}^{-1}$. Similarly, using 4-chlorophenol under solar irradiation conditions, the $\mathrm{N}$-doped sample at $500^{\circ} \mathrm{C}$ substantially out-performed the undoped sample. These results are discussed in the context of the effect of increasing temperature on the nature of the band gap.
\end{abstract}

Crown Copyright @ 2011 Published by Elsevier B.V. All rights reserved.

\section{Introduction}

Titanium dioxide $\left(\mathrm{TiO}_{2}\right)$ has become one of the most researched semiconductor materials due to the great promise it has shown in the photocatalytic oxidation of organic minerals $[1,2]$. The $\mathrm{TiO}_{2}$ photocatalytic process involves the formation of highly oxidising radical species through the creation of an electron $\left(\mathrm{e}^{-}\right)$, hole $\left(\mathrm{h}^{+}\right)$pair upon absorption of a photon of light that exceeds the band gap energy $(3.2 \mathrm{eV}$ or $\mathrm{h} v<390 \mathrm{~nm})$. [3] The powerful oxidising potential of $\mathrm{TiO}_{2}$ was first demonstrated in 1972 by Fujishima and Honda through the photocatalytic splitting of water in a photoelectrochemical cell [4]. Despite the great promise shown by titanium dioxide, there are some drawbacks. The primary issue facing researchers associated with semiconductor photocatalysis is the large band gap of $\mathrm{TiO}_{2}(3.2 \mathrm{eV})$ [5], meaning that only ultraviolet light $(\mathrm{h} v<390 \mathrm{~nm})$ can initiate the photocatalytic process,

\footnotetext{
* Corresponding author. Tel.: +353114027946.

E-mail address: Suresh.pillai@dit.ie (S.C. Pillai).
}

therefore limiting the practical use of $\mathrm{TiO}_{2}$ to $\leq 5 \%$ of the solar energy that reaches the earth's surface [5]. In order to overcome this difficulty it is necessary for researchers to modify the semiconductor band gap, thus facilitating visible light absorption and allowing the photocatalytic reaction to become more efficient under solar light irradiation. Asahi et al. [6] successfully demonstrated visible light absorption of a $\mathrm{TiO}_{2}$ semiconductor through nitrogen doping. They concluded that substitutional $\mathrm{N}$ doping causes band gap narrowing through $\mathrm{N} 2 \mathrm{p}$ orbitals mixing with $\mathrm{O} 2 \mathrm{p}$ orbitals [6]. However, further investigations into what causes visible light absorption of $\mathrm{N}-\mathrm{TiO}_{2}$ has subsequently been carried out by a number of researchers. Ihara et al. [7] suggested that oxygen vacancies cause visible light activity and that the addition of nitrogen merely stabilises these oxygen vacancies. Visible light absorption through the addition of oxygen vacancies was also reported by Martyanov et al. [2]. However there now appears to be some agreement regarding the fine electronic details of $\mathrm{N}$ doped visible light absorption as reported by Irie [8] and Nakamura [9]. It is now believed that oxygen lattice sites within the $\mathrm{TiO}_{2}$ crystal are substituted by nitrogen atoms $[10,11]$. The presence of these additional nitrogen atoms 
form an occupied midgap ( $\mathrm{N} 2 \mathrm{p}$ ) level above the $\mathrm{TiO}_{2}(\mathrm{O} 2 \mathrm{p})$ valence band. The $\mathrm{N} 2 \mathrm{p}$ band therefore acts as a step between the valence and the conduction band of the semiconductor, facilitating excitation of electrons from the $\mathrm{N} 2 \mathrm{p}$ mid-gap band to the conduction band upon irradiation with visible light $[8,9]$.

Titanium dioxide is made up of $\mathrm{TiO}_{6}$ octahedra [12]. The arrangement of these octahedra gives rise to three different polymorphs of titanium dioxide; anatase, rutile and brookite. Rutile is the thermodynamically stable form [13], while anatase and brookite are both metastable. Anatase and rutile are the most widely investigated polymorphs, with anatase being reported as the most photocatalytically active of the three $[3,14,15]$. Typically, anatase transforms to rutile under heat treatment $\left(600-700^{\circ} \mathrm{C}\right)[16,17]$. Parameters that affect the anatase-to-rutile transformation include; particle shape/size [18], source effects [19], atmosphere [20], reaction conditions [21] and purity [22]. Surface defect concentration [23] and grain boundary concentration [24] dominate the anatase-to-rutile phase transformation temperature. It has been previously shown by researchers that $\mathrm{N}$-doping supports the formation of $\mathrm{O}$ vacancies $[2,25]$. The presence of oxygen vacancies also enhances the anatase-to-rutile transformation [26-28], by facilitating the atomic rearrangement required for anatase-to-rutile transformation to occur [26].

The current paper reports a novel sol-gel technique for the synthesis of $\mathrm{N}-\mathrm{TiO}_{2}$. X-ray diffraction shows how the crystallisation behaviour of the materials is affected by the inclusion of a nitrogen source (1,3-diaminopropane) in the sol-gel reaction. Spectroscopic studies show chelation of 1,3-diaminopropane to the titanium alkoxide precursor resulting in the stabilisation of the titanium isopropoxide monomer and inhibiting the formation of polymeric metal oxide chains. Electronic spectra indicate insertion of nitrogen into the $\mathrm{TiO}_{2}$ lattice, and XPS reveals the chemical state of the atomic species as well as providing information on the mode of insertion (interstitial or substitutional) of atomic nitrogen within the $\mathrm{TiO}_{2}$ lattice. Photocatalytic studies under irradiation with a $60 \mathrm{~W}$ light bulb reveal that the $\mathrm{N}$-doped $\mathrm{TiO}_{2}$ powders calcined at $500{ }^{\circ} \mathrm{C}$ have greater photocatalytic activity compared to the undoped samples prepared under similar conditions.

\section{Experimental}

A 1:0.5, titanium:nitrogen precursor suspension was synthesised as follows. Titanium tetraisopropoxide $(10 \mathrm{~mL})$ was added to 1,3 -diaminopropane $(1.39 \mathrm{~mL}$, DAP) under stirring resulting in the formation of a white liquid-gel substance. Water $(59.4 \mathrm{~mL})$ was added to the gel to give a white paste. The paste suspension was allowed to stir for two hours before the liquid was filtered off leaving a white powder, which was then dried in air at $100^{\circ} \mathrm{C}$ for $24 \mathrm{~h}$. The dried powder was ground into a fine, white powder with mortar and pestle before being calcined at temperatures ranging from 500 to $900^{\circ} \mathrm{C}$ for two hours at a ramp rate of $5{ }^{\circ} \mathrm{C} / \mathrm{min}$. A control $\mathrm{TiO}_{2}$ sample was synthesised without the addition of 1,3diaminopropane. Titanium tetraisopropoxide $(10 \mathrm{~mL})$ was added to water $(59.4 \mathrm{~mL})$ under stirring and the resulting powder was filtered, dried and calcined in an identical manner to $\mathrm{TiO}_{2}$ prepared using nitrogen source.

Methylene blue is an accepted model organic pollutant for photocatalytic degradation studies and is used as an industrial standard (Japanese standard, JIS R 1703-2:2007) as such it was used to demonstrate the photocatalytic efficiency of the synthesised $\mathrm{TiO}_{2}$ powders. Crystalline $\mathrm{TiO}_{2}(60 \mathrm{mg})$ was added to methylene blue solution $\left(50 \mathrm{~mL}, 1 \times 10^{-5} \mathrm{M}\right)$ and stirred in the dark for $30 \mathrm{~min}$ to allow adsorption of the dye onto the photocatalyst before being placed under a $60 \mathrm{~W}$ light bulb and irradiated (radiation intensity is $1.2 \mathrm{~W} / \mathrm{m}^{2}$ ) with continuous stirring. $5 \mathrm{~mL}$ aliquots were

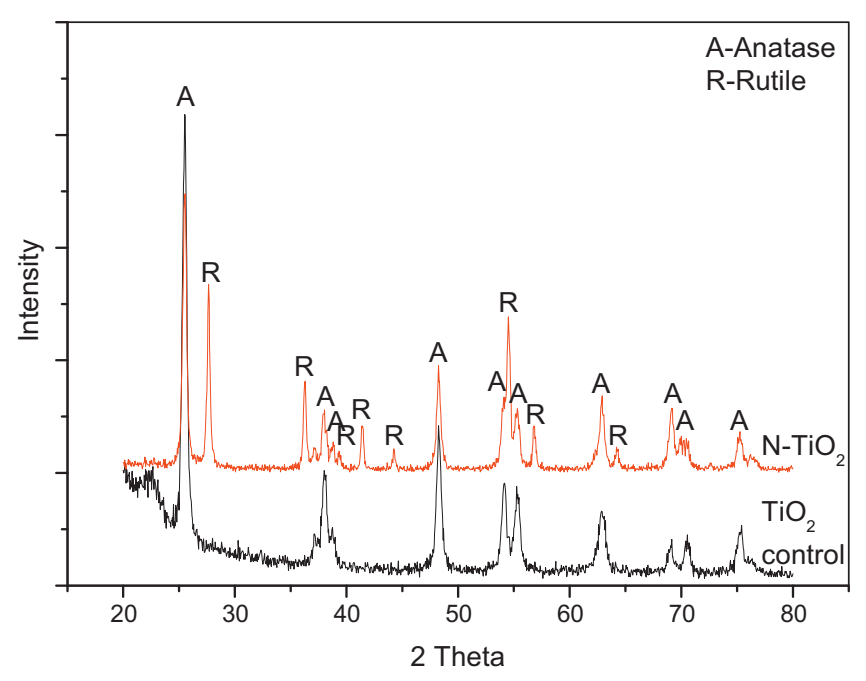

Fig. 1. $\mathrm{XRD}$ of $\mathrm{TiO}_{2}$ control and $\mathrm{N}-\mathrm{TiO}_{2}$ calcined at $600^{\circ} \mathrm{C}$.

withdrawn at timed intervals and the visible absorption spectrum was measured using a PerkinElmer Lambda 900 UV-vis spectrometer.

A degradation test was also carried out under simulated solar irradiation conditions in a Q-sun solar chamber (average radiation intensity is $0.66 \mathrm{~W} / \mathrm{m}^{2}$ ). $\mathrm{TiO}_{2}$ and 4-chlorophenol solution were exposed to light in the Q-sun, with aliquots taken at timed intervals and analysed by UV-vis spectroscopy. Crystalline $\mathrm{TiO}_{2}(25 \mathrm{mg}$ ) was added to 4-chlorophenol solution $(50 \mathrm{~mL}, 10 \mathrm{mg} / \mathrm{L})$ and stirred in the dark for 30 min to allow for absorption of the compound onto the photocatalyst. The solution containing the photocatalyst was then exposed to simulated solar irradiated with continuous stirring.

A Siemens D 500 X-ray diffractometer, with a diffraction angle range $2 \theta=20-80^{\circ}$ using $\mathrm{Cu} \mathrm{K} \alpha$ radiation was used to collect XRD diffractograms. XPS analyses were performed on a Thermo VG Scientific (East Grinstead, UK) ESCALAB Mk II spectrometer.

Surface area and pore size measurements were carried out using a Micrometrics Gemini VI Surface Area and Pore Analyser. The samples were degassed at $300^{\circ} \mathrm{C}$ for $2 \mathrm{~h}$ prior to measurements. Scanning electron microscope images were obtained using a Hitachi SU-70 FE-SEM.

A PerkinElmer Lambda 900 UV-vis absorption spectrophotometer was used to record absorption and diffuse reflectance spectra, samples were mixed in $\mathrm{KBr}(1: 20$ sample $\mathrm{KBr})$ and pressed into a tablet, a $\mathrm{KBr}$ tablet made under the same conditions was used as a reference. Infrared spectra were obtained using a PerkinElmer GX FTIR spectrometer and recorded as a $\mathrm{KBr}$ disc (1:10 sample/KBr). Approximately $5 \mathrm{mg}$ of sample was placed into an aluminium sample pan for DSC using an empty aluminium pan as a reference. All DSC were recorded on a Shimadzu DSC-60 between $25^{\circ} \mathrm{C}$ and $600^{\circ} \mathrm{C}$ at a ramp rate of $5^{\circ} \mathrm{C} / \mathrm{min}$.

\section{Results}

\subsection{X-ray diffraction}

The synthesised nitrogen doped and undoped titanium dioxide powders were calcined at temperatures $500-900{ }^{\circ} \mathrm{C}$ and the crystalline phases were determined using XRD (Fig. 1).

The XRD results show that at $500{ }^{\circ} \mathrm{C}$, anatase is the only $\mathrm{TiO}_{2}$ phase present for both samples. As the calcination temperature is increased to $600{ }^{\circ} \mathrm{C}$ rutile begins to form for $\mathrm{N}-\mathrm{TiO}_{2}$ but $\mathrm{TiO}_{2}$ control is anatase only. At $700^{\circ} \mathrm{C}$, anatase and rutile are present for both 
Table 1

Phase composition of $\mathrm{TiO}_{2}$ and $\mathrm{N}-\mathrm{TiO}_{2}$.

\begin{tabular}{llll}
\hline Sample $(\mathrm{Ti}: \mathrm{N})$ & Calcination temp. $\left({ }^{\circ} \mathrm{C}\right)$ & $\%$ Anatase & \% Rutile \\
$\mathrm{TiO}_{2}$ control & 600 & 100 & 0 \\
$\mathrm{TiO}_{2}$ control & 700 & 19 & 81 \\
$\mathrm{~N}-\mathrm{TiO}_{2}(1: 0.5)$ & 600 & 54 & 46 \\
$\mathrm{~N}-\mathrm{TiO}_{2}(1: 0.5)$ & 700 & 6 & 94 \\
\hline
\end{tabular}

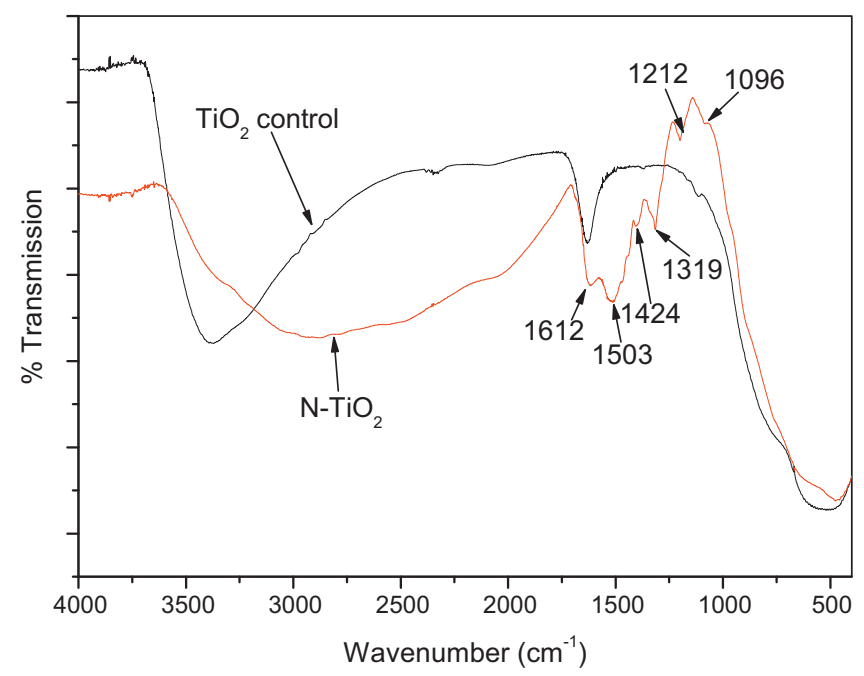

Fig. 2. Infrared spectrum of doped and undoped $\mathrm{TiO}_{2}$ before calcination.

samples but there is a greater percentage (Table 1) transformation for $\mathrm{TiO}_{2}$ control ( $0 \%$ to $81 \%$ rutile) compared to $\mathrm{N}-\mathrm{TiO}_{2}$ ( $46 \%$ to $94 \%$ ) rutile. At $800^{\circ} \mathrm{C}$, complete phase transformation from anatase to the stable rutile has occurred for doped and undoped $\mathrm{TiO}_{2}$.

The inclusion of nitrogen increases the rutile percentage at $600{ }^{\circ} \mathrm{C}(46 \%)$ upon comparison with the control sample (0\%). However, at $700{ }^{\circ} \mathrm{C}, \mathrm{TiO}_{2}$ control undergoes phase transformation to $81 \%$ rutile with $\mathrm{N}-\mathrm{TiO}_{2}$ retaining the anatase phase (6\%). To determine the effect 1,3-diaminopropane on the crystallisation behaviour of the materials, spectroscopic investigation of the amorphous powders was carried out.

\subsection{FTIR spectroscopy}

To determine how 1,3-diaminopropane interacts with TTIP, infrared spectra of $\mathrm{N}-\mathrm{TiO}_{2}$ and $\mathrm{TiO}_{2}$ control were recorded before the samples were calcined (Fig. 2) and the relative peaks were assigned (Table 2) [29-31].

Upon comparison of the spectral profile of $\mathrm{TiO}_{2}$ control with $\mathrm{N}-\mathrm{TiO}_{2}$ an apparent difference is clear. The spectrum of $\mathrm{N}-\mathrm{TiO}_{2}$ gives several strong signals in the region $1000-1700 \mathrm{~cm}^{-1}$ while for $\mathrm{TiO}_{2}$ control a peak at $1631 \mathrm{~cm}^{-1}$ representative of adsorbed $\mathrm{H}_{2} \mathrm{O}$ was the only peak in the same region. Both spectra show a broad peak from 400 to $1000 \mathrm{~cm}^{-1}$ caused by a Ti-O stretch. X-ray crystallography has previously shown that both the nitrogen atoms from diaminopropane coordinate to metal centres to form a six membered ring [32-35]. The IR spectrum of $\mathrm{N}-\mathrm{TiO}_{2}$ shown in Fig. 2

Table 2

Assigned frequencies for IR spectra of $\mathrm{N}-\mathrm{TiO}_{2}$ and $\mathrm{TiO}_{2}$ control.

\begin{tabular}{ll}
\hline Observed frequency $\left(\mathrm{cm}^{-1}\right)$ & Assignments \\
\hline 1612 & $\mathrm{NH}_{2}$ deformation \\
1503 & $\mathrm{NH}_{2}$ deformation \\
1424 & $\mathrm{CH}_{2}$ deformation \\
1319 & $\mathrm{CH}_{2}$ deformation \\
1212 & $\mathrm{CH}_{2} / \mathrm{NH}_{2}$ twist \\
1096 & $\mathrm{C}-\mathrm{N}$ stretch \\
\hline
\end{tabular}

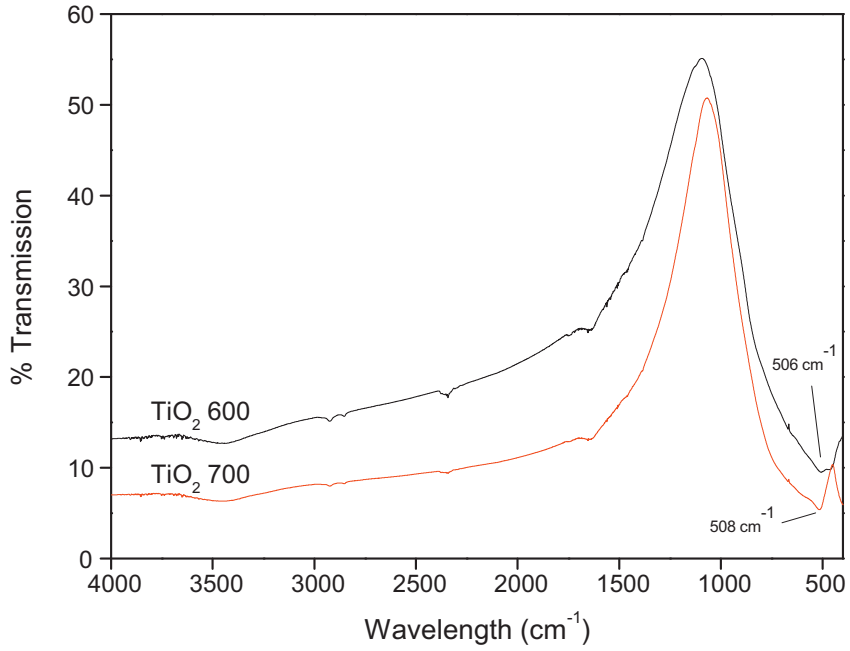

Fig. 3. Infrared spectrum of $\mathrm{N}$-doped $\mathrm{TiO}_{2}$ calcined at $600^{\circ} \mathrm{C}$ and $700^{\circ} \mathrm{C}$.

shows signals at 1612 and $1503 \mathrm{~cm}^{-1}$ caused by $\mathrm{NH}_{2}$ vibrations indicating that nitrogen is chelated to the titanium metal centre, increasing its coordination number to six and forming a chelated complex.

Modification of titanium alkoxides with chelating agents is known to promote thermally stable anatase phase at increased temperatures $\left(>800^{\circ} \mathrm{C}\right)[36,37]$. However, the employment of chelating agents for the synthesis of stable anatase typically involves the formation of bridging structures that promote the formation of polymeric chains with extensive cross linking [38]. These chains remain stable throughout much of the condensation process, resulting in extended anatase-to-rutile transformation temperatures [39-41]. The opposite is occurring with the addition of diaminopropane and instead of the formation of a highly branched polymeric structure, monomeric titanium amine structures are formed that may interact with neighbouring titanium amines through hydrogen bonding. During the condensation process the monomeric structures with little or no cross-linking are structurally weak and will readily collapse under calcination to form rutile as was seen through XRD.

The infrared spectra of the calcined $\mathrm{N}-\mathrm{TiO}_{2}$ (Fig. 3 ) shows a peak located at $508 \mathrm{~cm}^{-1}$. The peak is at higher energy than would be expected for an undoped $\mathrm{TiO}_{2}$ and have previously been assigned to the formation of $\mathrm{O}-\mathrm{Ti}-\mathrm{N}$ and $\mathrm{N}-\mathrm{Ti}-\mathrm{N}$ bond formation. [42] The infrared spectra of the $\mathrm{N}-\mathrm{TiO}_{2}$ calcined at $500^{\circ} \mathrm{C}$ shows no peaks in this region, indicating that the $\mathrm{Ti}-\mathrm{N}$ bond has not formed.

\subsection{Differential scanning calorimetry}

To examine the thermal events associated with the doped and undoped $\mathrm{TiO}_{2}$ powders, differential scanning calorimetry (DSC) was carried out. A clear difference between $\mathrm{TiO}_{2}$ control and $\mathrm{N}-\mathrm{TiO}_{2}$ was observed from the resulting DSC profile (Fig. 4).

An endothermic peak was observed at $\sim 100^{\circ} \mathrm{C}$ for both doped and undoped $\mathrm{TiO}_{2}$, which represents unbound water being removed from the $\mathrm{TiO}_{2}$ surface [16]. However, for undoped $\mathrm{TiO}_{2}$ the endothermic peak was of greater intensity indicating a greater capacity for the material to absorb water due to increased porosity. A minor exothermic peak at $\sim 400^{\circ} \mathrm{C}$ for $\mathrm{TiO}_{2}$ control indicates crystallisation of amorphous $\mathrm{TiO}_{2}$ to anatase. This was the only other thermal event of note observed for $\mathrm{TiO}_{2}$ control. From XRD results, $\mathrm{N}-\mathrm{TiO}_{2}$ was found to be amorphous at $400{ }^{\circ} \mathrm{C}$ with anatase present at $500^{\circ} \mathrm{C}$. From DSC, a large endothermic peak beginning at $\sim 400^{\circ} \mathrm{C}$ for $\mathrm{N}-\mathrm{TiO}_{2}$ is indicative of the removal of 1,3-diaminopropane that was shown to be adsorbed through FTIR (Fig. 2). The removal of 


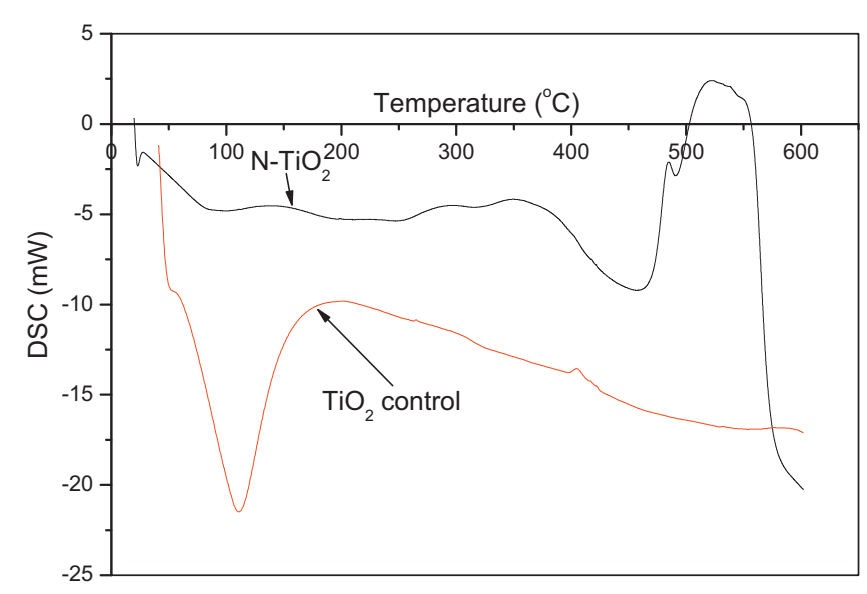

Fig. 4. DSC of doped and undoped $\mathrm{TiO}_{2}$.

the amine leads into an exothermic peak below $500^{\circ} \mathrm{C}$ representing the crystallisation of the material to anatase, which is in agreement with XRD results.

\subsection{Diffuse reflectance}

Upon visual inspection, $\mathrm{N}-\mathrm{TiO}_{2}$ calcined at $500^{\circ} \mathrm{C}$ was seen to be capable of visible light absorption as seen by the pale yellow colour of the powder [25]. Light absorption characteristics of the powders were investigated using diffuse reflectance.

Diffuse reflectance spectra of the nitrogen doped $\mathrm{TiO}_{2}$ powders calcined at $500{ }^{\circ} \mathrm{C}$ (Fig. 5) clearly show visible light absorption by the powders, indicating successful insertion of nitrogen into the $\mathrm{TiO}_{2}$ lattice. Infrared and diffuse reflectance spectroscopic results indicate nitrogen titanium interactions both before and after calcination up to $500^{\circ} \mathrm{C}$. Powders calcined at temperatures $\geq 600^{\circ} \mathrm{C}$ showed no visible light absorption, indicating band gap widening or ejection of nitrogen from the $\mathrm{TiO}_{2}$ lattice. Nitrogen atoms can occupy either interstitial or substitutional sites within the $\mathrm{TiO}_{2}$ lattice. Both types of nitrogen insertion are reported to give rise to localised states within the band gap of $\mathrm{TiO}_{2}$ resulting in visible light absorption [25]. X-ray photoelectron spectroscopy (XPS) is commonly employed to determine the interactions between nitrogen and the $\mathrm{TiO}_{2}$ lattice.

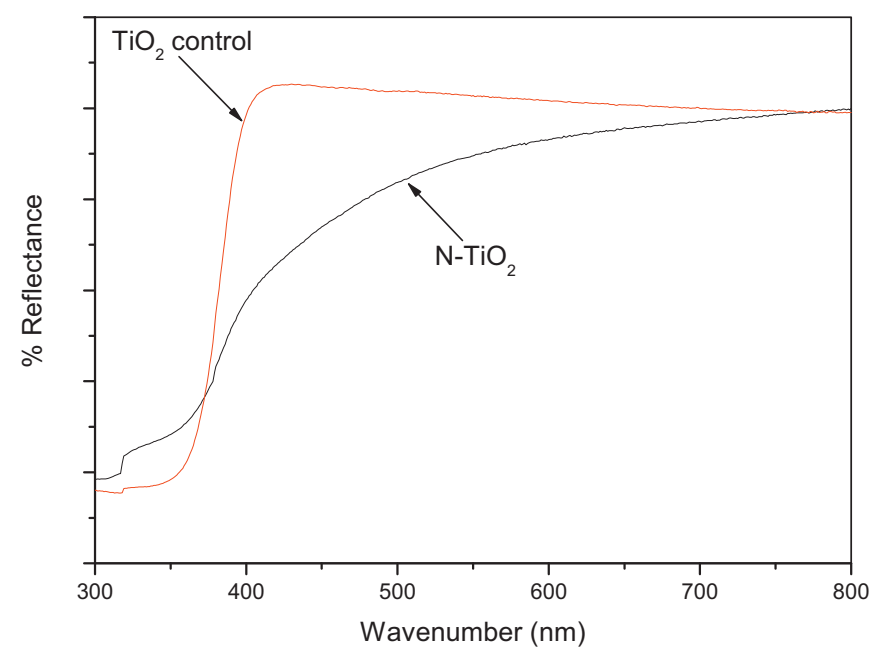

Fig. 5. Diffuse reflectance spectra of $\mathrm{TiO}_{2}$ and $\mathrm{N}-\mathrm{TiO}_{2}$ calcined at $500{ }^{\circ} \mathrm{C}$.
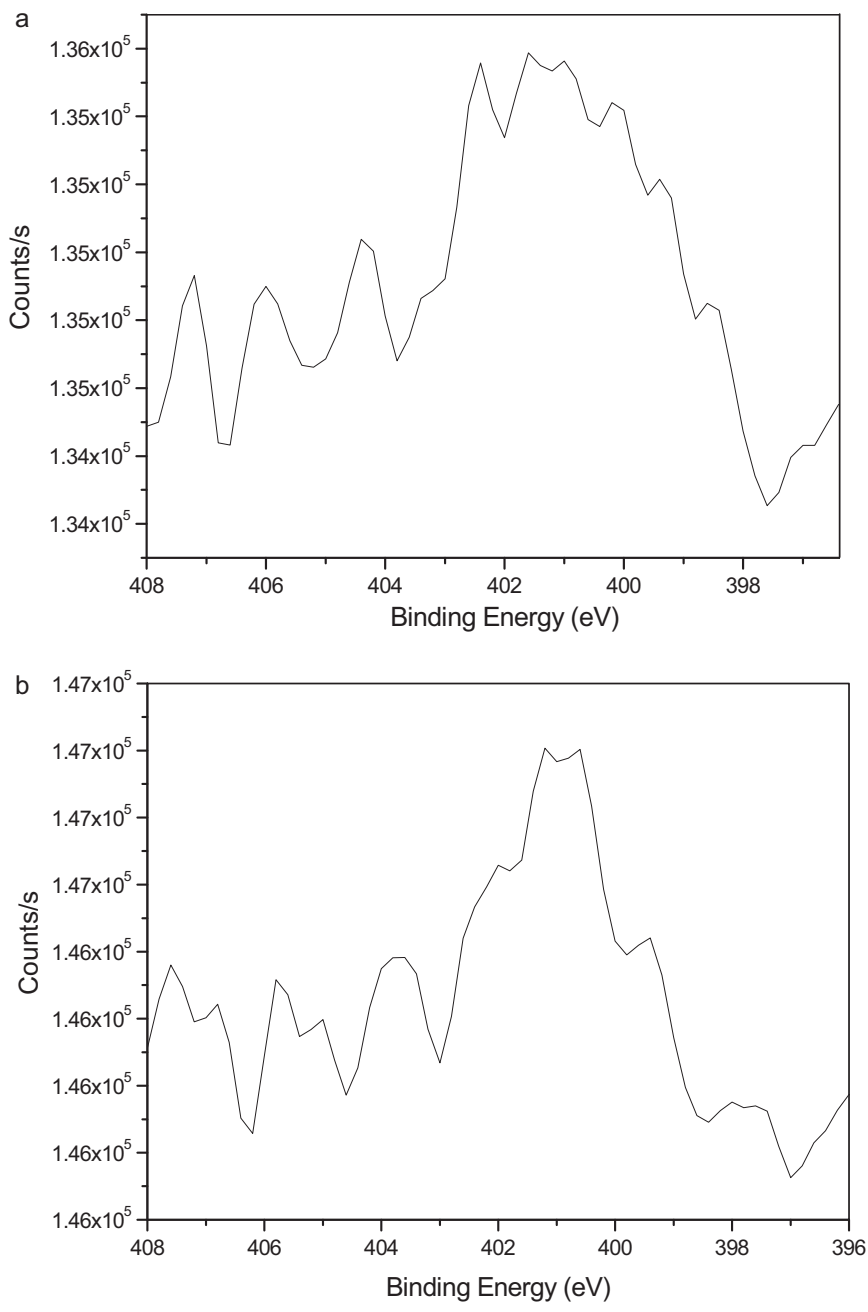

Fig. 6. $\mathrm{N} 1 \mathrm{~s}$ XPS spectra of $(1: 0.5) \mathrm{N}-\mathrm{TiO}_{2}$ calcined at (a) $500^{\circ} \mathrm{C}$, (b) $600^{\circ} \mathrm{C}$.

\subsection{X-ray photoelectron spectroscopy}

The $\mathrm{N} 1 \mathrm{~s}$ spectra of $\mathrm{N}-\mathrm{TiO}_{2}$ calcined at temperatures 500 and $600{ }^{\circ} \mathrm{C}$ are shown in Fig. 6. X-ray photoelectron spectroscopy peak assignment for $\mathrm{N}-\mathrm{TiO}_{2}$ is still under some debate [25], but it is generally accepted that $\mathrm{N} 1 \mathrm{~s}$ peaks at $396-397 \mathrm{eV}$ are representative of substitutional nitrogen $[25,43]$ while peaks at binding energies $>400 \mathrm{eV}$ are usually ascribed to $\mathrm{NO}(401 \mathrm{eV})$ or $\mathrm{NO}_{2}(406 \mathrm{eV})$ indicating interstitial nitrogen [43]. The XPS spectra in Fig. 6, show peaks with binding energies of $\sim 401 \mathrm{eV}$ which is higher than the typical $\mathrm{N} 1 \mathrm{~s}$ value but can be attributed to the binding of the $1 \mathrm{~s}$ electron of $\mathrm{N}$ in the environment of $\mathrm{O}-\mathrm{Ti}-\mathrm{N}$ in lattice $\mathrm{N}$-doped $\mathrm{TiO}_{2}$. The change in binding energy is due to the $\mathrm{N}$ substituting for oxygen in the $\mathrm{O}-\mathrm{Ti}-\mathrm{O}$ structure and the electron density around nitrogen becoming reduced compared to that of a TiN crystal, due to the presence of the oxygen atom [42]. This observation is consistent with literature on the oxidation of TiN surfaces [44].

Di Valentin et al. [25] employed density functional theory (DFT) to demonstrate interstitial nitrogen within anatase $\mathrm{TiO}_{2}$. Through DFT it was shown that there is no noticeable shift in the conduction or valence bands of the $\mathrm{TiO}_{2}$. With interstitial $\mathrm{N}$, localised $\pi$ character states are generated by the NO bond [25]. Two deep energy bonding states lie below the valence band and two antibonding $\mathrm{N} 2 \mathrm{p}$ states also lie above the valence band. It is the antibonding $\mathrm{NO}$ orbitals above the $\mathrm{TiO}_{2}$ valence band that facilitate visible light absorption by acting as a stepping stone for excited electrons between conduction and valence bands (Fig. 7). 


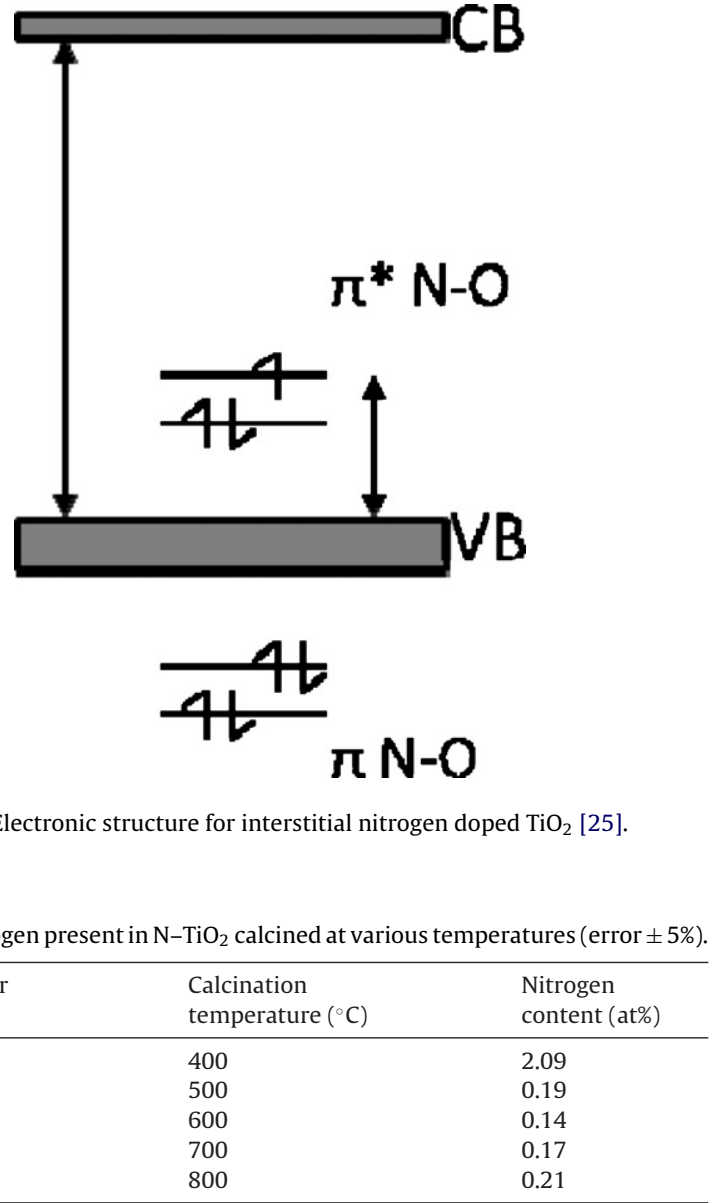

Table 3

Amount of nitrogen present in $\mathrm{N}-\mathrm{TiO}_{2}$ calcined at various temperatures (error $\pm 5 \%$ ).

\begin{tabular}{lll}
\hline $\begin{array}{l}\text { Ti:N precursor } \\
\text { molar ratio }\end{array}$ & $\begin{array}{l}\text { Calcination } \\
\text { temperature }\left({ }^{\circ} \mathrm{C}\right)\end{array}$ & $\begin{array}{l}\text { Nitrogen } \\
\text { content }(\text { at\%) }\end{array}$ \\
\hline $1: 0.5$ & 400 & 2.09 \\
$1: 0.5$ & 500 & 0.19 \\
$1: 0.5$ & 600 & 0.14 \\
$1: 0.5$ & 700 & 0.17 \\
$1: 0.5$ & 800 & 0.21 \\
\hline
\end{tabular}

The atomic percentage of nitrogen in the $\mathrm{N}-\mathrm{TiO}_{2}$ samples calcined at increasing temperature is shown in Table 3 . The results from Table 3 are in contrast with the observations made from diffuse reflectance spectra. XPS results reveal that the nitrogen content at calcination temperatures of $\geq 500{ }^{\circ} \mathrm{C}$ show no appreciable change, compared to the $600^{\circ} \mathrm{C}$. XPS does show a considerable drop in nitrogen content between $400(2.09 \%)$ and $500{ }^{\circ} \mathrm{C}(0.19)$ which is in agreement with the removal of the adsorbed amine as shown through DSC.

The crystallisation behaviour of the $\mathrm{TiO}_{2}$ was shown to be influenced by nitrogen as was the light absorption properties. $\mathrm{N}-\mathrm{TiO}_{2}$ is no longer capable of visible light absorption at calcination temperatures $\geq 600^{\circ} \mathrm{C}$. Disappearance of visible light absorption coincided with rutile formation. Through XPS it was shown that nitrogen
Table 4

First order rate constants for methylene blue degradation with $\mathrm{N}-\mathrm{TiO}_{2}$.

\begin{tabular}{llll}
\hline Sample & $\begin{array}{l}\text { Ti:N molar } \\
\text { ratio }\end{array}$ & $\begin{array}{l}\text { Calcination } \\
\text { temperature }\left({ }^{\circ} \mathrm{C}\right)\end{array}$ & $\begin{array}{l}\text { Rate constant } \\
\left(\mathrm{min}^{-1}, \times 10^{-2}\right)\end{array}$ \\
\hline $\mathrm{N}-\mathrm{TiO}_{2}$ & $1: 0.5$ & 500 & 0.400 \\
$\mathrm{~N}-\mathrm{TiO}_{2}$ & $1: 0.5$ & 600 & 0.190 \\
$\mathrm{~N}^{-\mathrm{TiO}_{2}}$ & $1: 0.5$ & 700 & 0.220 \\
$\mathrm{TiO}_{2}$ control & N/A & 500 & 0.020 \\
$\mathrm{TiO}_{2}$ control & N/A & 600 & 0.160 \\
$\mathrm{TiO}_{2}$ control & N/A & 700 & 0.320 \\
$\mathrm{P}^{25}$ & N/A & N/A & 0.005 \\
\hline
\end{tabular}

is not ejected from the $\mathrm{TiO}_{2}$ lattice at increased temperatures up to $800^{\circ} \mathrm{C}$. Diffuse reflectance results revealed a loss of visible light activity for the $\mathrm{N}-\mathrm{TiO}_{2}$ powders calcined at $\geq 600^{\circ} \mathrm{C}$ which was believed to be caused by ejection of interstitial nitrogen at increased temperatures, however, XPS has shown that nitrogen remains within the lattice at all temperatures occupying interstitial sites [25,43]. X-ray diffraction results show the formation of rutile at temperatures $\geq 600^{\circ} \mathrm{C}$ which leads to the conclusion that the formation of rutile is the reason for the blue shift in the absorption properties of the materials. Di Valentin et al. explain that a blue shift is observed with $\mathrm{N}$-doped rutile because not only is the top of the $\mathrm{TiO}_{2}$ valence band lowered (by $0.4 \mathrm{eV}$ ) but the inserted $\mathrm{N} 2 \mathrm{p}$ levels are also lower in energy than the valence band of pure rutile $(0.05 \mathrm{eV})$ resulting in a band gap increase relative to pure rutile or anatase [25]. The increase in band gap energy observed between $\mathrm{N}-\mathrm{TiO}_{2}$ calcined at $500{ }^{\circ} \mathrm{C}$ compared with $\mathrm{N}-\mathrm{TiO}_{2}$ calcined at $600{ }^{\circ} \mathrm{C}$ agrees with the above theory and explains the occurrence of a blue shift upon rutile formation despite the presence of interstitial nitrogen.

The scanning electron microscope images show that the nitrogen doped titanium dioxide (Fig. 8(A)) has a porous structure in comparison to the undoped sample (Fig. 8(B)). The agglomerated particles are also found to be smaller than the undoped titania. The agglomerations of the $\mathrm{N}-\mathrm{TiO}_{2}$ are all less than $1 \mu \mathrm{m}$ in size while the undoped samples have agglomerates over $2 \mu \mathrm{m}$ in size. The surface area of the $\mathrm{N}-\mathrm{TiO}_{2}$ sample was found to be $20 \mathrm{~m}^{2} / \mathrm{g}$, which is higher than the undoped sample of $2 \mathrm{~m}^{2} / \mathrm{g}$. The smaller particle leads to a higher surface area which provides more sites for photocatalysis to take place. The $\mathrm{N}$-doped material was found to have a pore size distribution of between 2 and $4 \mathrm{~nm}$, resulting in the formation of a mesoporus material.

\subsection{Photocatalytic activity}

The photocatalytic performance of the synthesised powders under a household light source are shown in Table 4. As expected, the only sample that showed visible light absorbance $\left(\mathrm{N}-\mathrm{TiO}_{2}\right.$
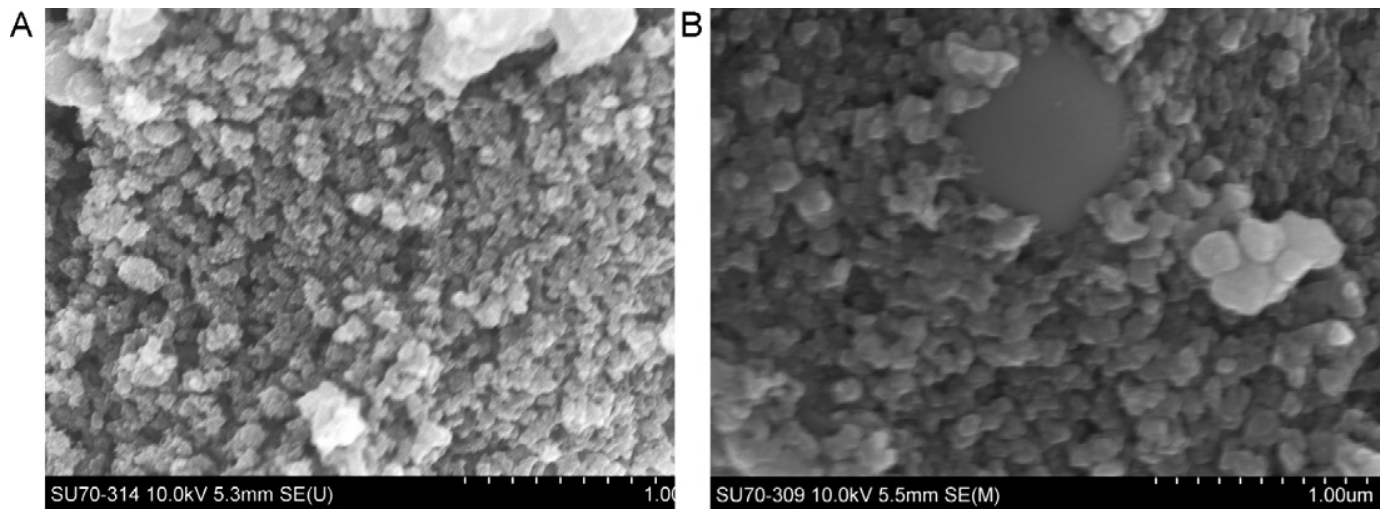

Fig. 8. Scanning electron microscope image of $(\mathrm{A}) \mathrm{N}$-doped $\mathrm{TiO}_{2}$ calcined at $500{ }^{\circ} \mathrm{C}$ and (B) undoped $\mathrm{TiO}_{2}$ calcined at $500{ }^{\circ} \mathrm{C}$. 


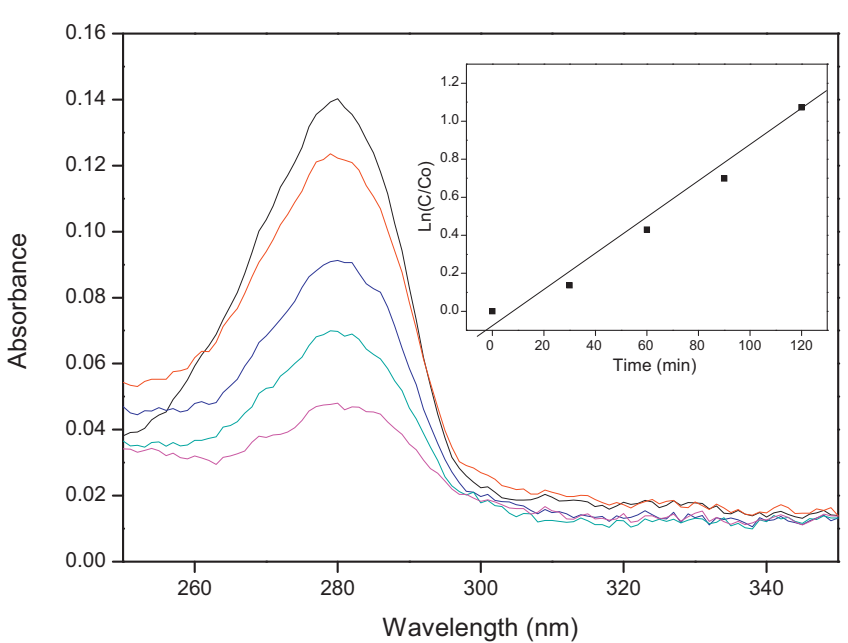

Fig. 9. Degradation of 4-chlorophenol using $\mathrm{N}-\mathrm{TiO}_{2}$ calcined at $500^{\circ} \mathrm{C}$ under irradiation from solar light in a Q-sun solar chamber.

calcined at $500^{\circ} \mathrm{C}$ ) was the best performing photocatalyst with a degradation reaction rate of $0.4 \times 10^{-2} \mathrm{~min}^{-1}$. Nitrogen doped $\mathrm{TiO}_{2}$ showed far greater photocatalytic activity under the $60 \mathrm{~W}$ light bulb when compared with the industrial standard, Degussa P25 which showed virtually zero degradation of methylene blue after $6 \mathrm{~h}$ of irradiation.

$\mathrm{N}-\mathrm{TiO}_{2}$ calcined at $700{ }^{\circ} \mathrm{C}$ shows slightly greater activity than $\mathrm{N}-\mathrm{TiO}_{2}$ calcined at $600^{\circ} \mathrm{C}$. Any photoactivity observed for $\mathrm{N}-\mathrm{TiO}_{2}$ calcined at 600 and $700^{\circ} \mathrm{C}$ was attributed to the presence of the lower band gap energy rutile ( $3.0 \mathrm{eV}$ or $400 \mathrm{~nm})$.

For the degradation of 4-chlorophenol, a model organic pollutant, the $\mathrm{N}$-doped titania sample calcined at $500^{\circ} \mathrm{C}$ was again found to be the most efficient. Under irradiation in a solar chamber, complete degradation of the 4-chlorophenol was found to occur in $2 \mathrm{~h}$. No degradation was observed for the control sample prepared under similar conditions. The samples prepared at higher temperatures did not show any photocatalytic activity, this is due to the formation of rutile at these higher temperatures, which is not photocatalytically active in the N-doped samples.

A degradation plot of 4-chlorophenol under irradiation from a solar chamber is shown in Fig. 9. The rate of degradation was found to obey first order kinetics and the rate constant was calculated from the first order plot. Lists of rate constants are shown for 4chlorophenol degradation in Table 5.

\section{Discussion}

FTIR results indicated the chelation of 1,3-diaminopropane to titanium tetraisopropoxide through nitrogen-titanium bonding and from XRD, DSC and XPS it could be seen that at calcination temperatures exceeding $400^{\circ} \mathrm{C}$, adsorbed 1,3-diaminopropane is removed and crystallisation occurs. Diffuse reflectance results demonstrated the ability of $\mathrm{N}-\mathrm{TiO}_{2}$ calcined at $500^{\circ} \mathrm{C}$ to absorb visible light. However, $\mathrm{N}-\mathrm{TiO}_{2}$ samples calcined at temperatures in excess of $500{ }^{\circ} \mathrm{C}$ showed no evidence of visible light absorbance indicating band gap widening. Through XPS it was determined that

\section{Table 5}

First order rate constants for 4-chlorophenol degradation with N-TiO under solar irradiation.

\begin{tabular}{llll}
\hline Sample & $\begin{array}{l}\text { Ti:N molar } \\
\text { ratio }\end{array}$ & $\begin{array}{l}\text { Calcination } \\
\text { temperature }\left({ }^{\circ} \mathrm{C}\right)\end{array}$ & $\begin{array}{l}\text { Rate constant } \\
\left(\mathrm{min}^{-1}, \times 10^{-2}\right)\end{array}$ \\
\hline${\mathrm{N}-\mathrm{TiO}_{2}}_{\mathrm{TiO}_{2} \text { control }}$ & 1:0.5 & 500 & 0.900 \\
\hline
\end{tabular}
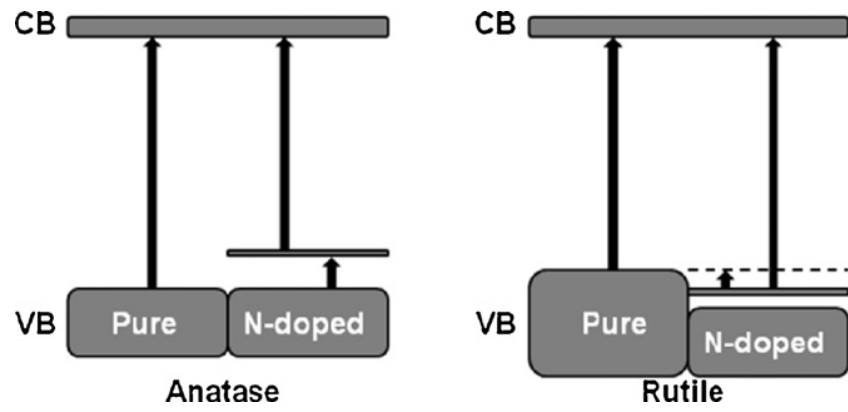

Fig. 10. Schematic electronic structure [23] for pure and N-doped anatase and rutile polymorphs of $\mathrm{TiO}_{2}$.

nitrogen remained within the $\mathrm{TiO}_{2}$ lattice at temperatures $>500{ }^{\circ} \mathrm{C}$ so it can therefore be postulated that the loss of visible light absorption is caused by band gap widening. A blue shift in the absorbance properties of $\mathrm{N}-\mathrm{TiO}_{2}$ samples calcined at $\geq 600^{\circ} \mathrm{C}$ coincides with the formation of rutile as shown through XRD. For $\mathrm{N}-\mathrm{TiO}_{2}$, rutile (46\%) was formed after calcination at $600{ }^{\circ} \mathrm{C}$. Although rutile possesses a smaller band gap than anatase, a blue shift is observed with rutile formation. This can be explained through the inclusion of nitrogen within rutile crystals. Di Valentin et al. [25] explain that a blue shift is observed with $\mathrm{N}$-doped rutile because not only is the top of the $\mathrm{TiO}_{2}$ valence band lowered (by $0.4 \mathrm{eV}$ ) but the inserted $\mathrm{N} 2 \mathrm{p}$ levels are also lower in energy than the valence band of pure rutile $(0.05 \mathrm{eV})$ resulting in an overall blue shift in the optical absorption of $\mathrm{N}$-doped rutile of $\sim 0.1 \mathrm{eV}$ (Fig. 10).

Anatase-to-rutile transformation can be dominated by effects such as defect concentration [21]. Nitrogen defects within the $\mathrm{TiO}_{2}$ lattice, may act as nucleation sites for the anatase-to-rutile transformation, facilitating the formation of rutile at low temperatures $\left(\geq 600^{\circ} \mathrm{C}\right)$. Induced low temperature rutile formation in the presence of nitrogen is contradictory to previous reports by this group [41]. It has been previously observed that using urea as a nitrogen source alters the condensation pathway, extending the temperature at which rutile forms [42]. However, the current study shows that 1,3-diaminopropane stabilises titanium tetraisopropoxide as a monomer which will contribute to the low temperature formation of rutile. The increased surface area of the $\mathrm{N}-\mathrm{TiO}_{2}$ sample $\left(20 \mathrm{~m}^{2} / \mathrm{g}\right)$ compared to the control sample $\left(2 \mathrm{~m}^{2} / \mathrm{g}\right)$ also contributed to the higher visible light active properties of $\mathrm{N}$-doped samples. From the FESEM studies it was further evident that the particles of the $\mathrm{N}$ doped samples were less agglomerated compared to the control samples.

Table 1 highlights the anatase/rutile percentages of the control $\mathrm{TiO}_{2}$ sample as well as the nitrogen doped sample. At $600{ }^{\circ} \mathrm{C} \mathrm{TiO}_{2}$ (control) is $100 \%$ anatase. However, $\mathrm{N}-\mathrm{TiO}_{2}$ calcined at the same temperature $\left(600^{\circ} \mathrm{C}\right)$ has begun to transform into rutile $(46 \%)$. Crystallisation results show that inclusion of nitrogen within the lattice reduces the anatase-to-rutile transformation temperature, which is accredited to nitrogen within the lattice acting as nucleation sites for the anatase-to-rutile transformation [42]. Substitutional nitrogen doping was also previously reported to improve the visible light photocatalytic activities of nitrogen doped anatase-rutile heterojunctions. However, in the current case the pure $\mathrm{N}$-doped anatase annealed at $500^{\circ} \mathrm{C}$ showed a better performance compared to an anatase-rutile mixture [43]. Another influencing factor for early rutile formation with nitrogen doped $\mathrm{TiO}_{2}$ is the increased formation of oxygen vacancies. Several researchers have demonstrated that nitrogen promotes the formation of oxygen vacancies within $\mathrm{TiO}_{2}$ [2,7]. Oxygen vacancies have also been widely reported to lower the anatase-to-rutile transformation temperature. Space is created within the crystal lattice with the presence of oxygen vacancies allowing ionic rearrangement to occur with greater ease, 
which is necessary for the structural changes that occur during the anatase-to-rutile transformation [14,24-26].

\section{Conclusions}

Titanium dioxide was successfully doped with nitrogen to create a visible light active photocatalyst. 1,3-diaminopropane was chosen as a nitrogen source and through infrared spectroscopy it was determined that diaminopropane chelates to titanium forming a six membered ring, the chelated titanium amine results in the formation of titanium isopropoxide monomeric units that readily form rutile at low temperatures as shown through XRD. XPS and DSC results showed that the material retains the adsorbed amine up to $400^{\circ} \mathrm{C}$ but at increased temperatures $\left(500^{\circ} \mathrm{C}\right)$ the material crystallises to anatase $\mathrm{TiO}_{2}$ with nitrogen inserted into the crystal lattice, present in interstitial sites as shown through XPS. Diffuse reflectance spectra of $\mathrm{N}-\mathrm{TiO}_{2}$ calcined at $500^{\circ} \mathrm{C}$ indicated the presence of $\mathrm{N} 2 \mathrm{p}$ bands between the valence band and conduction band of $\mathrm{TiO}_{2}$ allow for visible light absorption by the material. However, upon calcination at $\geq 600^{\circ} \mathrm{C}, \mathrm{N}-\mathrm{TiO}_{2}$ is no longer capable of visible light absorption, which coincides with the formation of rutile. This was attributed to a band gap extension in $\mathrm{N}$ doped rutile. The photocatalytic degradation of methylene blue and 4-chlorophenol was carried out under irradiation from a household light bulb (60 W) and using a Q-sun solar chamber respectively. The $\mathrm{N}-\mathrm{TiO}_{2}$ prepared at $500^{\circ} \mathrm{C}$ showed the highest amount of activity, higher than that of a control $\mathrm{TiO}_{2}$ sample and of Degussa P25 $\mathrm{TiO}_{2}$.

\section{Acknowledgements}

The authors wish to thank Science Foundation Ireland (SFI grant number 10/US/I1822) for supporting this investigation under the US-Ireland R\&D partnership programme, CREST and Focas for lab and office facilities and equipment. The authors would also like to thank Dr. John Colreavy for reviewing the paper and providing valuable comments and Michael Whelan for providing the scanning electron microscopy images. The authors would like to acknowledge Enterprise Ireland (CFTD/06/IT/326 and ARE/2008/0005) and Environmental Protection Agency (EPA) Ireland for funding.

\section{References}

[1] M.R. Hoffmann, S.T. Martin, W. Choi, D.W. Bahnemann, Environmental applications of semiconductor photocatalysis, Chem. Rev. 95 (1995) 69.

[2] I.N. Martyanov, S. Uma, S. Rodrigues, K.J. Klabunde, Structural defects cause $\mathrm{TiO}_{2}$-based photocatalysts to be active in visible light, Chem. Commun. 7 (2004) 2476.

[3] O. Carp, C.L. Huisman, A. Reller, Photoinduced reactivity of titanium dioxide, Prog. Solid State Chem. 32 (2004) 33.

[4] A. Fujishima, K. Honda, Electrochemical photolysis of water at semiconductor electrodes, Nature (1972) 238.

[5] T. Tachikawa, M. Fujitsuka, T. Majima, Mechanistic insight into the $\mathrm{TiO}_{2}$ photocatalytic reactions: design of new photocatalysts, J. Phys. Chem. C 111 (2007) 5259.

[6] R. Asahi, T. Morikawa, K. Oikawa, K. Aoki, Y. Taga, Visible-light photocatalysis in nitrogen-doped titanium oxides, Science 293 (2001) 269.

[7] T. Ihara, M. Miyoshi, Y. Iriyama, O. Matsumoto, S. Sugihara, Visible-light-active titanium oxide photocatalyst realized by an oxygen-deficient structure and by nitrogen doping, Appl. Catal. B 42 (2003) 403.

[8] H. Irie, Y. Watanabe, K. Hashimoto, Nitrogen-concentration dependence on photocatalytic activity of $\mathrm{TiO}_{2}-x \mathrm{~N} x$ Powders, J. Phys. Chem. B 107 (2003) 5483.

[9] R. Nakamura, T. Tanaka, Y. Nakoto, Mechanism for visible light responses in anodic photocurrents at $\mathrm{N}$-doped $\mathrm{TiO}_{2}$ film electrodes, J. Phys. Chem. B 108 (2004) 10617

[10] A.V. Emeline, V.N. Kuznetsov, V.K. Rybchuk, N. Serpone, Visible-light-active titania photocatalysts: the case of $\mathrm{N}$-doped $\mathrm{TiO}_{2}-$ properties and some fundamental issues, Int. J. Photoenergy 258 (2008) 1

[11] F. Spadavecchia, G. Cappelletti, S. Ardizzone, M. Ceotto, L. Falciola, Electronic structure of pure and $\mathrm{N}$-doped $\mathrm{TiO}_{2}$ nanocrystals by electrochemical experiments and first principal calculations, J. Phys. Chem. C 115 (2011) 6381.
[12] D. Nicholls, Complexes and First-Row Transition Elements, MacMillan Education, Hong Kong, 1974.

[13] Y. Hu, H.-L. Tsai, C.-L. Huangk, Effect of brookite phase on the anatase-rutile transition in titania nanoparticles, Eur. Ceram. Soc. 23 (2003) 691.

[14] J. Aguado, R. van Grieken, M.J. Lopez-Munoz, J. Marugan, Removal of cyanides in wastewater by supported $\mathrm{TiO}_{2}$-based photocatalysts, Catal. Today $75(2002)$ 95.

[15] U. Diebold, The surface science of titanium dioxide, Surf. Sci. Rep. 48 (2003) 53.

[16] N.T. Nolan, M.K. Seery, S.J. Hinder, L.F. Healy, S.C. Pillai, A systematic study of the effect of silver on the chelation of formic acid to a titanium precursor and the resulting effect on the anatase-to-rutile transformation of $\mathrm{TiO}_{2}$, J. Phys. Chem. C 114 (2010) 13026.

[17] N.T. Nolan, M.K. Seery, S.C. Pillai, Spectroscopic investigation of the anatase-torutile transformation of sol-gel-synthesized $\mathrm{TiO}_{2}$ photocatalysts, J. Phys. Chem. C 113 (2009) 16151.

[18] S.R. Yoganarasimhan, C.N.R. Rao, Mechanism of crystal structure transformations. Part 3. Factors affecting the anatase-rutile transformation, Trans. Faraday Soc. 58 (1962) 1579.

[19] C. Byun, J.W. Wang, L.T. Kim, K.S. Hong, B.W. Lee, Anatase-to-rutile transition of titania thin films prepared by MOCVD, Mater. Res. Bull. 32 (1997) 431.

[20] K.J.D. MacKenzie, The effect of reaction atmosphere and electric fields on the anatase-rutile transformation, Trans. J. Br. Ceram. Soc. 74 (1975) 121

[21] Y. Li, T.J. White, S.H. Lim, Low-temperature synthesis and microstructural control of titania nano-particles, J. Solid State Chem. 177 (2004) 1372.

[22] K.J.D. MacKenzie, The calcinations of titania: the effect of additive on the anatase-rutile transformation, Trans. J. Br. Ceram. Soc. 74 (1975) 29.

[23] H. Liu, S. Cheng, M. Wu, J. Zhang, W. Li, C. Cao, Photoelectrocatalytic degradation of sulfosalicylic acid and its electrochemical impedance spectroscopy investigation, J. Phys. Chem. A 104 (2000) 7016.

[24] Y.U. Ahn, E.J. Kim, H.T. Kim, S.H. Hahn, Variation of structural and optical properties of sol-gel $\mathrm{TiO}_{2}$ thin films with catalyst concentration and calcination temperature, Mater. Lett. 57 (2003) 4660.

[25] C. Di Valentin, E. Finazzi, G. Pacchioni, A. Selloni, S. Livraghi, M.C. Paganini, E. Giamello, N-doped $\mathrm{TiO}_{2}$ : theory and experiment, Chem. Phys. 339 (2007) 44.

[26] H.E. Chao, Y.U. Yun, H.U. Xingfang, A. Larbot, Effect of silver doping on the phase transformation and grain growth of sol-gel titania powder, ECERS 23 (2003) 1457.

[27] S. Hishita, I. Mutoh, K. Koumoto, H. Yanagida, Inhibition mechanism of the anatase-rutile phase transformation by rare earth oxides, Ceram. Intern. 9 (1982) 61

[28] K.J.D. MacKenzie, Calcination of titania. 5. Kinetics and mechanism of anatase-rutile transformation in presence of additives, J. Br. Ceram. Soc. 74 (1975) 77.

[29] A. Verma, S.B. Samanta, A.K. Bakhshi, S.A. Agnihotry, Effect of stabilizer on structural, optical and electrochemical properties of sol-gel derived spin coated $\mathrm{TiO}_{2}$ films, Sol. Energy Mater. Sol. Cells 88 (2005) 47.

[30] M. Krunks, I. Oja, K. Tonsuaadu, M. Es-Souni, M. Gruselle, L. Niinisto, Thermoanalytical study of acetylacetonate-modified titanium(IV) isopropoxide as a precursor for $\mathrm{TiO}_{2}$ films, J. Therm. Anal. Calorim. 80 (2005) 483.

[31] G. Socrates, Infrared and Raman Characteristic Group Frequencies, John Wiley \& Sons Ltd., Chichester, 2001.

[32] C. Bazzicalupi, A. Bencini, A. Bianchi, V. Fusi, P. Paoletti, B. Valtancoli, Unusual complexation behavior of 1,3-diaminopropane, Inorg. Chim. Acta 244 (1996) 255.

[33] J. Cernak, K.A. Abboud, J. Chomic, M.W. Meisel, M. Orendac, A. Orendacova, A. Feher, $\mathrm{Ni}(\mathrm{tn})(2) \mathrm{Ag}-2(\mathrm{CN})(4)$ and $\mathrm{Cu}(\mathrm{tn})(2) \mathrm{Ag}-2(\mathrm{CN})(4)(\mathrm{tn}=1,3-$ diaminopropane): preparation, crystal structure, magnetic and spectral properties, Inorg. Chim. Acta 311 (2000) 126.

[34] A.D. Legendre, A.E. Mauro, M.A.R. de Oliveira, M.T. do Prado Gambardella, A three-dimensional network constructed from the assembly of 1,3diaminopropane-copper(II) and tetracyanopalladate(II) moieties, Inorg. Chem. Comm. 11 (2008) 896.

[35] J. Lloyd, S.Z. Vatsadze, D.A. Robson, A.J. Blake, P. Mountford, New titanium imido complexes containing piperazine-based diamido-diamine ligands, J. Organomet. Chem. 591 (1999) 114.

[36] C. Suresh, V. Biju, P. Mukundan, K.G.K. Warrier, Anatase-to-rutile transformation in sol-gel titania by modification of precursor, Polyhedron 17 (1998) 3131.

[37] C.J. Brinker, G.W. Scherer, The Physics and Chemistry of Sol-Gel Science, Academic Press, New York, 1990.

[38] H.H. Kung, E.I. Ko, Preparation of oxide catalysts and catalyst supports-a review of recent advances, Chem. Eng. J. 64 (1996) 203.

[39] J. Livage, C. Sanchez, M. Henry, S. Doeuff, The chemistry of the sol-gel process, Solid State Ionics 32/33 (1989) 633.

[40] T.-V. Nguyen, D.-J. Choi, O.-B. Yang, Effect of chelating agents on the properties of $\mathrm{TiO}_{2}-\mathrm{SiO}_{2}$ mixed oxide for photocatalytic water decomposition, Res. Chem. Intermed. 31 (2005) 483.

[41] S.C. Pillai, P. Periyat, R. George, D.E. McCormack, M.K. Seery, H. Hayden, J. Colreavy, D. Corr, S.J. Hinder, Synthesis of high-temperature stable anatase $\mathrm{TiO}_{2}$ photocatalyst, J. Phys. Chem. C 111 (2007) 1605.

[42] V.Etacheri, M.K. Seery, S.J. Hinder, S.C. Pillai, Highly visible light active $\mathrm{TiO}_{2}-x \mathrm{~N} x$ heterojunction photocatalysts, Chem. Mater. 22 (2010) 3843.

[43] J. Ananpattarachai, P. Kajitvichyanukul, S. Seraphin, Visible light absorption ability and photocatalytic oxidation activity of various interstitial $\mathrm{N}$-doped $\mathrm{TiO}_{2}$ prepared from different nitrogen dopants, J. Hazard. Mater. 168 (2009) 253.

[44] N.C. Saha, H.C. Tomkins, J. Appl. Phys. 72 (1992) 3072. 